\title{
Cytological Effects of Acrylamide on Root Tip Cells of Allium cepa
}

\author{
Rishi Shanker, L. K. S. Chauhan and Prahlad K. Seth \\ Industrial Toxicology Research Centre, Post Box 80, Mahatma \\ Gandhi Marg, Lucknow-226 001, India
}

Accepted August 24, 1986

Acrylamide, a reactive vinyl monomer used in polymer industry is a potent neurotoxin (Tilson 1981). Acrylamide and its polymers are extensively used as grouting agent, soil stabiliser, flocculents in water treatment and industrial waste disposal (NIOSH 1976, Tilson 1981). The unreacted monomer from polymers with high monomer content $(0.3 \%)$, has been found to migrate into soil and subsequently into plants and water supplies (Croll et al. 1974, Igisu et al. 1975, Nishikawa et al. 1978, 1979). Nishikawa et al. $(1978,1979)$ reported the presence of monomer in various parts of rice seedling and chinese cabbage.

Little information is available on the cytological effects of acrylamide in plants and animals. Shiraishi (1978) reported chromatid exchange and breaks in spermatogonia of mice after long term exposure. An acrylamide analogue 2-(2-furyl)3-(5-nitro 2-furyl)-acrylamide $\left(\mathrm{AF}_{2}\right)$ used as a food preservative has been found to be mutagenic (Sugiyama et al. 1975, Takahashi 1975). In view of widespread distribution of acrylamide there is an urgent need to evaluate the cytogenetic effects of the monomer in plants. This paper deals with the effects of acrylamide on root tip cells of Allium cepa.

\section{Material and Methods}

Fresh and healthy root tips of $A$. cepa grown in distilled water were exposed to various concentrations of acrylamide. The roots were exposed either for $3 \mathrm{~h}$ to $1,2,5,10$ and $20 \mathrm{mM}$ acrylamide or for $24 \mathrm{~h}$ to 1,2 and $5 \mathrm{mM}$ acrylamide. Samples were taken from root tips of control and treated $A$. cepa and examined for the effect of acrylamide on the rate of cell division. In order to investigate, whether the damage if any, caused by acrylamide is reversible the control and treated root tips of $A$. cepa were left in distilled water upto 24 or $96 \mathrm{~h}$. The tip cells from control and exposed roots were examined at various intervals for chromosomal aberrations.

The root tips were fixed in freshly prepared Carnoy's fixative (alcohol: acetic acid, 3:1) and stained with haematoxylin (Darlington and La Cour 1976). Stained root tips were squashed in $45 \%$ acetic acid and the cells were screened under a light microscope.

\section{Results}

Acrylamide caused a decrease in mitotic index at all the concentrations tested. On exposure to $20 \mathrm{mM}$ of acrylamide the mitotic index was 1.00 as compared to 3.11 in the respective control while there was a significant increase in the metaphase index (Table 1). The abnormalities noted in metaphase cells were chromosome and chromatid breaks (Fig. 2), fragmentation (Fig. 3) and stickiness (Fig. 4). The frequency of chromosome breaks was greater than other aberrations, while chromatid breaks were observed only at higher concentrations of acrylamide (Table 2).

The abnormalities observed in anaphase were multipolar arrangement (Fig. 5), unequal distribution (Fig. 6) and laggards (Fig. 7). No signs of recovery in any of the changes were 
evident upto $6 \mathrm{~h}$ of the recovery period. By $24 \mathrm{~h}$ considerable recovery was evident in the root tip cells exposed to acrylamide for a period of $3 \mathrm{~h}$ only (Table 2).

The incubation of root tips with acrylamide for a prolonged period of $24 \mathrm{~h}$ caused similar aberrations with greater intensity and produced new abnormalities like chromosomal bridges (Fig. 8). However, aberrations such as stickiness, micronuclei and chromosomal bridges were observed even upto $96 \mathrm{~h}$ of the recovery period (Table 3).
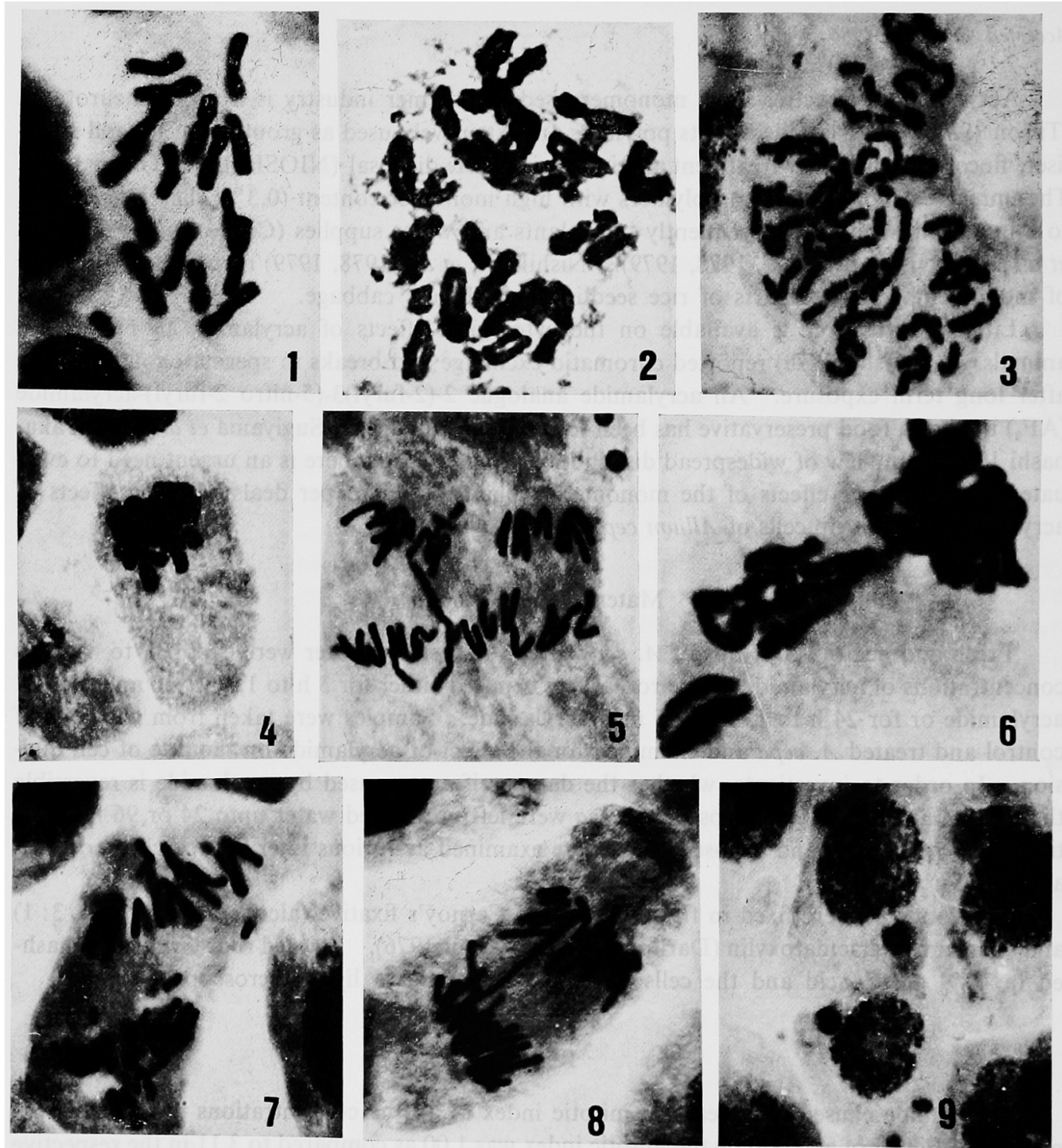

Figs. 1-9. Aberrations induced by Acrylamide in root tip cells of Allium cepa. 1, normal chromosomes. 2, chromosome and chromatid breaks. 3, fragmentation of chromosomes. 4, stickiness of chromosomes. 5, multipolar arrangement of chromosomes. 6, unequal distribution of chromosomes. 7, laggards in anaphase stage. 8, chromosomal bridges. 9, micronucleated cells.

Discussion

The mitodepressive action of acrylamide is suggested by the continuous fall of mitotic 
index in the root tip cells. Our findings are in some way parallel to those of Shiraishi (1978), who reported high mitotic reduction in spermatogonial cells of mice treated with acrylamide indicating that the chemical damages the cytoplasmic microtubules and spindles. Well clarified metaphase arrest in treated cells after long recovery periods might be a sign of inhibition of spindle action which also led to spreading of chromosomes all over the cell plate. The inhibitory action on the function of spindles might be due to the binding of acrylamide with pro-

Table 1. Effect of acrylamide exposure ( $3 \mathrm{~h}$ ) on cell division of root tip cells of $A$. cepa

\begin{tabular}{ccccc}
\hline \hline $\begin{array}{c}\text { Concentration } \\
\text { of acrylamide } \\
(\mathrm{mM})\end{array}$ & Mitotic index & Prophase index & Metaphase index & Anaphase index \\
\hline Control & $\mathbf{3 . 1 1} \pm \mathbf{0 . 2 4}$ & $43.78 \pm 1.77$ & $\mathbf{2 7 . 2 3} \pm 0.89$ & $16.33 \pm 1.29$ \\
1 & $3.13 \pm 0.05$ & $43.45 \pm 0.87$ & $30.98 \pm 1.00$ & $8.37 \pm 0.66$ \\
2 & $2.78 \pm 0.07$ & $43.06 \pm 0.62$ & $37.18 \pm 0.85^{\mathrm{b}}$ & $10.60 \pm 0.68^{\mathrm{a}}$ \\
5 & $1.64 \pm 0.03^{\mathrm{a}}$ & $28.69 \pm 0.87^{\mathrm{a}}$ & $54.50 \pm 3.82^{\mathrm{a}}$ & $7.48 \pm 0.17^{\mathrm{a}}$ \\
10 & $1.49 \pm 0.03^{\mathrm{a}}$ & $20.22 \pm 1.96^{\mathrm{a}}$ & $58.26 \pm 1.02^{\mathrm{a}}$ & $6.36 \pm 0.45^{\mathrm{a}}$ \\
20 & $1.00 \pm 0.04^{\mathrm{a}}$ & $17.96 \pm 2.39^{\mathrm{a}}$ & $64.31 \pm 1.45^{\mathrm{a}}$ & $5.79 \pm 1.02^{\mathrm{a}}$ \\
\hline
\end{tabular}

Data represents mean \pm S.E. (data obtained from 8,000 to 10,000 cells taken from the root tips selected at random).

$\mathrm{a}=\mathrm{p}<0.01$ as compared to control.

$\mathrm{b}=\mathrm{p}<0.02$ as compared to control.

Table 2. Aberrations and recovery pattern in meta-anaphase cells of root tips of $A$. cepa exposed to acrylamide for $3 \mathrm{~h}$

\begin{tabular}{|c|c|c|c|c|c|c|c|c|c|c|}
\hline \multirow{2}{*}{$\begin{array}{c}\mathrm{ACR} \\
(\mathrm{mM})\end{array}$} & \multirow{2}{*}{$\begin{array}{l}\text { Recovery } \\
\text { time } \\
\text { (h) }\end{array}$} & \multirow[b]{2}{*}{$\begin{array}{c}\text { Number } \\
\text { of } \\
\text { cells } \\
\text { analysed }\end{array}$} & \multicolumn{8}{|c|}{$\%$ Aberrations } \\
\hline & & & $\begin{array}{c}\text { C- } \\
\text { mitotic }\end{array}$ & $\begin{array}{c}\text { Chro- } \\
\text { mosome } \\
\text { breaks }\end{array}$ & $\begin{array}{l}\text { Chro- } \\
\text { matid } \\
\text { breaks }\end{array}$ & $\begin{array}{c}\text { Sticki- } \\
\text { ness }\end{array}$ & $\begin{array}{l}\text { Frag- } \\
\text { men- } \\
\text { tation }\end{array}$ & $\begin{array}{c}\text { Multi- } \\
\text { polar } \\
\text { arrange- } \\
\text { ment }\end{array}$ & $\begin{array}{c}\text { Unequal } \\
\text { distri- } \\
\text { - bution }\end{array}$ & $\begin{array}{c}\text { Total } \\
\text { ab- } \\
\text { normal } \\
\text { cells }\end{array}$ \\
\hline \multirow[t]{4}{*}{2} & 6 & 225 & 2.22 & 4.88 & - & 1.88 & - & - & 1.33 & 10.28 \\
\hline & 12 & 205 & 0.97 & 2.92 & - & 1.46 & - & 1.95 & 1.46 & 8.76 \\
\hline & 18 & 209 & - & 2.39 & - & 1.47 & - & - & 0.95 & 4.81 \\
\hline & 24 & 225 & - & - & - & 1.33 & - & - & 0.88 & 2.21 \\
\hline \multirow[t]{4}{*}{5} & 6 & 245 & 2.85 & 9.38 & 1.22 & 2.85 & 1.63 & 0.81 & 1.22 & 19.96 \\
\hline & 12 & 215 & 3.72 & 8.83 & 1.39 & 2.32 & 1.39 & 1.39 & 1.39 & 20.43 \\
\hline & 18 & 226 & - & 1.76 & - & 1.88 & - & 0.88 & 1.32 & 5.84 \\
\hline & 24 & 235 & - & 1.27 & - & 1.70 & - & 0.42 & 1.27 & 5.11 \\
\hline \multirow[t]{4}{*}{10} & 6 & 215 & 5.11 & 7.90 & 3.25 & 3.72 & 3.25 & 1.86 & 3.93 & 29.06 \\
\hline & 12 & 222 & 5.85 & 8.10 & 0.90 & 2.25 & 1.35 & 2.25 & 3.60 & 24.30 \\
\hline & 18 & 234 & - & 3.84 & - & 1.28 & - & 1.28 & 2.56 & 8.96 \\
\hline & 24 & 220 & - & 2.27 & - & 1.81 & 0.90 & 1.36 & 1.81 & 8.15 \\
\hline \multirow[t]{4}{*}{ Control } & 6 & 265 & - & 0.75 & - & 0.75 & - & - & - & 1.50 \\
\hline & 12 & 230 & - & 0.86 & - & 0.48 & - & - & - & 1.29 \\
\hline & 18 & 210 & - & 0.35 & - & 0.65 & - & - & - & 1.00 \\
\hline & 24 & 250 & - & 0.80 & - & 0.25 & - & - & - & 1.05 \\
\hline
\end{tabular}

teins which help in spindle formation as reported in case of colchicine, a potent spindle inhibitor. The binding of acrylamide with spindle proteins is quite probable due to the presence of vinyl group in the molecule which makes it highly reactive. Furthermore, acrylamide has been shown to bind to proteins involved in its detoxification (Dixit et al. 1980, 1981).

The abnormalities like multipolar arrangement, unequal distribution and bridges in anaphase observed in the root tip cells exposed to acrylamide may be due to the failure of spindle 
formation in treated cells. Exposure to acrylamide for prolonged periods was found to produce certain permanent changes as chromosomal bridges and micronuncleated cells which were detectable even upto $96 \mathrm{~h}$ of the recovery period. Such effects observed in acrylamide treated cells might be due to the mild disturbances in $G_{1}$ and $S$ phase of the cell cycle. Similar abnormalities have been observed in $A$. cepa treated with iso-propyl phenyl carbamate (Doxey 1949) and deltamethrin (Chauhan et al. 1986). The inhibition of spindle formation has been shown to lead to severe abnormalities such as stickiness, unequal distribution, multipolar anaphase, chromosomal bridges and laggards (Amer and Ali 1968, Badr 1983).

The present study suggests that long term exposure to acrylamide can lead to certain irreversible cytogenetic effects in plants. The observation is of significance inview of the wide-

Table 3. Aberrations and recovery pattern in root tip cells of $A$. cepa exposed to acrylamide for $24 \mathrm{~h}$

\begin{tabular}{|c|c|c|c|c|c|c|c|c|c|}
\hline \multirow[b]{2}{*}{$\begin{array}{c}\mathrm{ACR} \\
(\mathrm{mM})\end{array}$} & \multirow[b]{2}{*}{$\begin{array}{l}\text { Recovery } \\
\text { time } \\
\text { (h) }\end{array}$} & \multirow[b]{2}{*}{$\begin{array}{c}\text { Number } \\
\text { of } \\
\text { cells } \\
\text { analysed }\end{array}$} & \multicolumn{7}{|c|}{$\%$ Aberrations } \\
\hline & & & $\begin{array}{c}\text { Chromo- } \\
\text { some } \\
\text { breaks }\end{array}$ & $\begin{array}{c}\text { Sticki- } \\
\text { ness }\end{array}$ & $\begin{array}{l}\text { Multi- } \\
\text { polar } \\
\text { arrange- } \\
\text { ment }\end{array}$ & Bridges & Laggards & $\begin{array}{l}\text { Micro- } \\
\text { nuclei }\end{array}$ & $\begin{array}{c}\text { Total } \\
\text { abnormal } \\
\text { cells }\end{array}$ \\
\hline \multirow[t]{5}{*}{1} & 8 & 325 & 3.93 & 2.12 & 2.81 & 3.43 & 1.56 & 1.53 & 15.38 \\
\hline & 16 & 260 & 3.10 & 1.72 & 1.60 & 3.60 & 1.60 & 1.68 & 13.30 \\
\hline & 24 & 234 & 2.01 & 1.21 & 1.80 & 2.29 & - & 1.61 & 8.92 \\
\hline & 48 & 255 & 1.66 & 1.33 & 1.40 & 2.36 & - & - & 6.75 \\
\hline & 96 & 225 & - & 0.93 & - & 1.73 & - & - & 2.66 \\
\hline \multirow[t]{5}{*}{2} & 8 & 280 & 5.48 & 3.55 & 3.60 & 5.20 & 1.60 & 2.11 & 21.54 \\
\hline & 16 & 272 & 2.09 & 2.69 & 3.33 & 4.28 & 1.90 & 2.38 & 16.67 \\
\hline & 24 & 242 & 1.11 & 2.59 & 2.80 & 1.47 & 0.94 & 2.29 & 11.42 \\
\hline & 48 & 252 & - & 2.55 & 1.30 & 1.50 & - & 1.81 & 7.16 \\
\hline & 96 & 275 & - & 1.66 & - & 1.20 & - & 0.85 & 3.71 \\
\hline \multirow[t]{5}{*}{5} & 8 & 277 & 5.88 & 5.39 & 4.40 & 5.20 & 2.80 & 3.00 & 26.67 \\
\hline & 16 & 235 & 3.33 & 3.75 & 3.91 & 4.75 & 2.21 & 4.41 & 22.36 \\
\hline & 24 & 244 & 1.48 & 2.96 & 1.83 & 2.75 & 1.31 & 3.43 & 13.76 \\
\hline & 48 & 277 & 1.49 & 2.39 & 1.36 & 2.73 & - & 2.22 & 10.19 \\
\hline & 96 & 250 & - & 1.85 & - & 1.30 & - & 1.26 & 4.41 \\
\hline \multirow[t]{5}{*}{ Control } & 8 & 245 & 1.22 & 0.80 & - & - & - & - & 2.02 \\
\hline & 16 & 250 & 0.80 & 0.40 & - & - & - & - & 1.20 \\
\hline & 24 & 225 & - & 0.80 & - & - & - & - & 0.80 \\
\hline & 48 & 217 & 0.46 & 0.92 & - & - & - & - & 1.38 \\
\hline & 96 & 205 & 0.47 & - & - & - & - & - & 0.47 \\
\hline
\end{tabular}

spread use and presence of acrylamide in terrestrial and aquatic ecosystems. If similar mechanisms were to operate in higher organisms, acrylamide exposure can lead to genetic effects in them. This is further strengthened by the findings of Shiraishi (1978) that meiotic cells are highly sensitive to acrylamide.

\section{Summary}

Acrylamide monomer has wide variety of applications which lead to its release into soils and water ways. The cytogenetic effects of acrylamide were investigated in roots of Allium cepa. The chemical exerted mitodepressive action on mitosis and induced a number of chromosomal changes and mitotic abnormalities. Chromosomal changes produced comprised of chromosome and chromatid breaks, fragmentation and stickiness in metaphase cells. An- 
aphase cells showed multipolar arrangement, unequal distribution, chromosomal bridges and micronucleated cells. Some of these effects appeared to be irreversible. The study suggests that continuous exposure to acrylamide may lead to genetic effects in plants and even higher organisms.

\section{Acknowledgement}

The authors are thankful to Dr. P. K. Ray, Director, Industrial Toxicology Research Centre, Lucknow for his interest. Thanks are also due to Dr. V. Sundraraman, ITRC, Lucknow for his valuable suggesttions. One of us (R.S.) is grateful to Department of Environment, Government of India, for the award of Senior Research Fellowship.

\section{References}

Amer, S. M. and Ali, E. M. 1968. Cytological effect of pesticides IV. Mitotic effects of some phenols. Cytologia 34: 533-540.

Badr. A. 1983. Mitodepressive and chromotoxic activities of two herbicides in Allium cepa. Cytologia 48: $451-457$.

Croll, B. T., Arkell, G. M. and Hodge, R. P. J. 1974 . Residues of acrylamide in water. Water Res. 8: 989-993.

Chauhan, L. K. S., Dikshith, T. S. S. and Sundraraman, V. 1986. Effect of deltamethrin on plant cells I. Cytological effects on the root meristems of Allium cepa. Mutat. Res. 171: 25-30.

Darlington, C. D. and LaCour, L. F. 1976. The Handling of Chromosomes. Allen and Unwin, London.

Dixit, R., Mukhtar, H., Seth, P. K. and Krishna Murti, C. R. 1980. Binding of acrylamide with glutathione-stransferase. Chem. Biol. Interact. 32: 353-359.

-, Mukhtar, H., Seth, P. K. and Krishna Murti, C. R. 1981. Conjugation of acrylamide with glutathione catalysed by glutathione-s-transferase of rat liver and brain. Biochem. Pharmacol. 30: 1739-1744.

Doxey, D. 1949. The effect of iso-propyl phenyl carbamate on mutation in Secale cereale and onion (Allium cepa). Ann. Bot. 13: 329-336.

Igisu, H., Goto, I., Kawamura, Y., Kato, M, Izumi, K. and Kuroiwa, Y. 1975. Acrylamide encephaloneuropathy due to well water pollution. J. Neurol. Neurosurg. Psych. 38: 581-584.

NIOSH, 1976. Criteria for recommended standard occupational exposure to acrylamide. U. S. Department of Health, Education and Welfare, U.S.A.

Nishikawa, H., Muto, Y., Sonada, Y. and Miyaki, Y. 1978. Effects of high molecular coagulants on agricultural crops. Gifu-Ken Kogyo Gijutsu Senta Kenkyu Hokoku (Japan). 10: 5-8.

-, Hosomura, H., Sonada, Y. and Inagaki, S. 1979, Behaviour of acrylamide in soil plant systems. Gifu-Ken Kogyo Gijutsu Senta Kenkyu Hokoku (Japan), 11: 31-34.

Shiraish, Y. 1978. Chromosome aberrations induced by monomeric acrylamide in bone marrow and germ cells of mice. Mutat. Res. 57: 313-324.

Sugiyama, T., Goto, K. and Uenaka, H. 1975. Acute cytogenetic effect of 2-(2-furyl)-3(5-nitro-2-furyl)-acrylamide $\left(\mathrm{AF}_{2}\right.$, a food preservative) on rat bone marrow cells in vivo. Mutat. Res. 31: 241-246.

Takahashi, K. 1975. Statistical analysis on toxicity of a nitrofuran derivative, 2-(2-furyl)-3-(5-nitro-2-furyl)acrylamide. Tohoku J. Exp. Med. 115: 167-183.

Tilson, H. A. 1981. Neurotoxicity of acrylamide. A overview. Neurobehav. Toxicol. Teratol. 3: 445-461. 